\title{
Research on Carbon Accounting Information Disclosure of Chinese Power Enterprises
}

\author{
Yuting Qian \\ School of Economics and Management, North China Electric Power University, Beijing 100000, \\ China
}

Keywords: Carbon accounting; power companies; information disclosure

\begin{abstract}
With the development of the economy and society, the pace of urbanization has been accelerating, and environmental problems caused by air pollution have become increasingly prominent. The development of low-carbon economy has made carbon accounting as a branch of environmental accounting on the world stage, providing guarantee for the realization of low-carbon economy. Currently in China, power companies based on thermal power are high-carbon enterprises. This paper first introduces the current research status of carbon accounting; secondly analyzes the theoretical basis of carbon accounting information disclosure; then through sample survey, according to the carbon accounting information disclosure of power listed companies, discusses the current status and problems of carbon accounting implementation in China's power companies; In response to relevant issues, it proposes countermeasures for the development of carbon accounting in China's power companies.
\end{abstract}

\section{Introduction}

As China's rapid economic development, environmental problems such as haze weather and global warming have gradually entered people's sights. The original extensive economic development model no longer adapts to China's national conditions. Advancing anti-fouling treatment, developing carbon accounting, and protecting the ecological environment have become increasingly urgent. On the morning of April 1, 2018, the Shanghai Pudong New Area Taxation Bureau issued the first environmental protection tax stamp for Bass Materials Co., Ltd., marking the implementation of the Environmental Protection Tax Law of the People's Republic of China ${ }^{[1]}$. At the same time that China's environmental legal system is gradually improved, carbon accounting is still in its infancy, and the disclosure of carbon accounting information by enterprises is still not perfect. Vigorously developing carbon accounting is conducive to understanding pollution from the source, is conducive to the optimization and upgrading of industrial structure, and accelerates the development of low-carbon economy.

Foreign carbon accounting research is relatively mature. Norway was the first country to propose the concept of carbon accounting ${ }^{[2]}$. In 2008, Stewart Jones and Janek Ratnatunga made a preliminary definition of the concept of carbon accounting ${ }^{[3]}$. In the same year, Kolk, A., D. Levy \& J. Pinkse pointed out that carbon accounting is mainly composed of carbon sink assets recognition and carbon source liabilities recognition, and on this basis, it is proposed that enterprises should establish corresponding accounting systems ${ }^{[4]}$. However, Francisco Ascui (2011) pointed out that the accounting academic community has not reached a consensus on the definition of carbon accounting concepts. China's carbon accounting theory research is still in its infancy ${ }^{[5]}$. Wang Aiguo (2012) proposed that China's carbon accounting should include at least carbon accounting, carbon cost accounting, carbon management accounting and carbon auditing, etc ${ }^{.6]}$. Liang Liang (2018) pointed out that carbon accounting, confirmation, measurement and information disclosure are the most important ${ }^{[7]}$.

As a typical representative of high-carbon enterprises, power companies should strengthen the disclosure of carbon accounting information and provide a good reference for decision-makers. At the same time, according to the information disclosed, improve the energy structure of the enterprise, develop a low-carbon economy, and meet the social needs of current energy-saving emission reduction and low-carbon environmental protection. 


\section{Contents and Methods of Carbon Accounting Information Disclosure in Power Companies}

\subsection{Contents of carbon accounting information disclosure}

Carbon accounting information disclosure includes two aspects: First, accounting information that can be quantitatively calculated. Such information has monetary measurement attributes and can be disclosed to the public as a formal reporting item; rather, it can only be qualitatively managed carbon accounting. Information, such information can not be expressed in currency, nor can it be directly reflected in the financial statements. Generally, it can only be indicated in text form in the notes of the statement or corporate social responsibility report, and such disclosure is more common.

\subsubsection{Accounting type carbon accounting information disclosure content}

The object of accounting carbon accounting information disclosure is the carbon consumption and carbon emission movement that the power enterprise can measure in the daily production and operation activities. Similar to basic accounting elements, carbon accounting elements can be roughly divided into six categories:

(1)Carbon accounting assets: Including the carbon emission quotas that the government directly allocates to power companies every year; the inflows that the enterprises bring economic benefits to the company by selling the remaining quotas generated by their own energy-saving and emission-reduction technologies; the technology, patents, etc. are all carbon accounting assets.

(2)Carbon accounting liabilities: Carbon accounting liabilities mainly include unpaid fines due to excessive carbon emissions from power companies; loans for the development of low-carbon technologies; liabilities arising from insufficient carbon emission quotas.

(3) Carbon accounting equity: Carbon accounting equity refers to the rights formed by the owner's low-carbon resources invested in various forms, mainly including the investment and subsidies obtained by participating in low-carbon projects at home and abroad.

(4)Carbon accounting income: Carbon accounting income mainly comes from the direct or indirect income brought by enterprises participating in low-carbon activities, including the income from the sale of carbon emission quotas by enterprises, and the indirect increase of relevant energy-saving and emission reduction project bonuses and tax incentives, income, etc.

(5)Carbon accounting expenses: The carbon accounting expenses are mainly the environmental recovery costs incurred by the enterprise in the production and operation process, the environmental pollution control costs, the energy saving and emission reduction technologies or the amortization expenses of the patented entities, and the carbon emission trading is the expenditure incurred. Wait.

(6) Carbon accounting profit: Carbon accounting profit is the net amount of carbon accounting income of power companies after deducting carbon accounting expenses in a certain period. It can faithfully translate the low carbon performance achieved by enterprises in production and operation activities.

2.1.2 Management type carbon accounting information disclosure content

The management carbon accounting information disclosure mainly includes qualitative information of the written description, including the use of carbon emission rights acquired by the enterprise during the year; whether the pollutants discharged exceeds the standard; the measures and technical means adopted by enterprises for energy conservation and emission reduction; carbon emissions Annual change analysis, etc.

\subsection{Ways of Carbon Accounting Information Disclosure in Power Enterprises}

The way carbon accounting information is disclosed depends mainly on the specific content of carbon accounting information. Information on accounting-type carbon accounting elements that can be measured in monetary terms can be disclosed in the form of financial statements; for qualitative management-type carbon accounting information that cannot be measured in monetary terms, it can be explained in the notes to the financial statements and in the corporate social responsibility report. . 
Generally speaking, carbon accounting information disclosure of power companies has the following forms:

2.2.1 Integrating carbon accounting elements into traditional financial statement accounts

This approach is to increase the corresponding carbon accounting project in the existing financial reporting system, thus forming a disclosure of carbon accounting elements information. Power companies can disclose relevant carbon accounting information in detail in the details of the original report items. For example, in the balance sheet item, low-carbon inventory under the inventory item, low-carbon trading financial assets under the transactional financial assets project, low-carbon fixed assets under the fixed assets project, and carbon emission rights of the enterprise according to certain criteria. In order to reflect the carbon accounting assets and carbon accounting liabilities that the company has at the end of the accounting period; in the income statement item, the low-carbon operating income and expenses under the operating income items are differentiated from the chess market expenses, so as to reflect the enterprise's The operating results of low-carbon operations and carbon trading in a certain accounting period.

2.2.2 Separate preparation of corporate carbon accounting financial statements

This method is independent of the original financial accounting system, and independently prepares a set of financial statements for enterprise carbon accounting information based on certain accounting standards and business management requirements. Including the carbon accounting balance sheet prepared according to the three elements of carbon accounting assets, carbon accounting liabilities and carbon accounting equity, once reflecting the survival of the end-of-year carbon assets of the enterprise; the enterprise carbon prepared according to the three elements of accounting income, carbon accounting cost and carbon accounting profit The accounting income statement reflects the low-carbon business results of the enterprise during the accounting period; similarly, the carbon accounting cash flow of the enterprise can be divided into three parts: low-carbon business activities, low-carbon investment activities, and low-carbon financing activities, and the enterprise carbon is compiled accordingly. The accounting cash flow statement reflects the cash inflows and outflows generated by the company in the low carbon segment.

\subsubsection{Periodic disclosure of corporate carbon accounting information report}

For management-type carbon accounting information that cannot be quantified into relevant accounting statements, enterprises can express them in the form of words, icons, etc., and as a note to the company's financial statements or a separate corporate carbon accounting information report, so that stakeholders can obtain corporate carbon in a timely and accurate manner.

\section{Current Status and Problems of Carbon Accounting Implementation in Power Companies}

In this paper, the 30 companies in the Shenzhen and Shanghai A-shares that are mainly based on thermal power generation are divided into three groups according to the operating profit, and two power companies are selected as samples in each group. Among them, group A is operating profit. High group, group $\mathrm{C}$ is the group with lower operating profit. By comparing and comparing the carbon accounting information disclosed in the 2017 annual report and social responsibility report of the six companies, the current status and problems of carbon accounting information disclosure of China's power companies are as follows:

\subsection{Current status of carbon accounting implementation in power companies}

Among the six listed companies listed in the thermal power generation, only one group A company quantitatively disclosed the transfer income of the carbon emission rights quota in the annual report in the annual report, and included it in non-operating income. None of the other five companies disclosed the transfer income of the relevant carbon emission allowances separately in the financial report. And none of the six listed companies separately listed other carbon accounting information in the financial report, such as the value of low-carbon intangible assets and the value of carbon emission rights.

Among the six listed companies listed in the thermal power generation, only one C Group Company has neither disclosed the CSR report to the public nor disclosed the relevant carbon 
accounting information in the annual report. It is difficult for information users to find the enterprise to save energy and reduce emissions and low carbon. Contributions to environmental protection. On the contrary, the company has also been listed as a key emitter, attracting investors' attention.

Among the Group A enterprises with the best enterprise benefits, they can quantitatively disclose carbon accounting information such as carbon emissions information, waste detection results, and environmental protection inputs in corporate social responsibility reports or corporate environmental reports.

Group A and Group B with relatively good benefits can disclose the company's management-type carbon accounting information in the social responsibility report, including energy conservation and emission reduction awards, environmental technology achievements, compliance with emission standards, and energy consumption optimization. These enterprises are also able to actively respond to the government's call to actively develop new energy projects such as hydropower and wind power on the basis of the original thermal power business, and disclose them in the social responsibility report.

On the contrary, in the Group $C$ enterprises with relatively poor benefits, both companies as samples were separately disclosed corporate social responsibility reports. A company only stated in its annual report that the company implemented relevant environmental regulations, did not disclose the specific detailed and useful carbon accounting information of the company, and the disclosure of carbon accounting information was in the form.

\subsection{Carbon Accounting Implementation Issues in Power Enterprises}

\subsubsection{Free access to carbon accounting information}

China has not made specific provisions on the way of corporate carbon accounting information disclosure. Therefore, the way for power companies to disclose carbon accounting information is arbitrary. The management of power companies adopts notes such as financial statements, board reports, and social responsibility reports. The complicated information disclosure channels reduce the availability and comparability of carbon accounting information, which is not conducive to timely access to effective information by information users.

\subsubsection{Carbon accounting information disclosure content is arbitrary}

In China, there is no formal carbon accounting information disclosure standard to regulate the content and quality of corporate carbon accounting information disclosure. Carbon accounting information disclosure relies on management decision-making. Therefore, the carbon accounting information disclosure tends to "report the news and not report the worry". The management has certain motives to conceal the carbon accounting information that is not conducive to the image of the company, such as specific carbon emissions, to the information users, so as to obtain additional investment by using information asymmetry or subsidy. At the same time, due to the lack of uniform standards for carbon accounting information disclosure, the carbon information of each enterprise is not comparable.

\subsubsection{Power companies pay less attention to carbon accounting information}

Although most power companies can respond to the national call for voluntary disclosure of carbon accounting information, the carbon accounting information disclosed by power companies is mostly qualitative description, and as an auxiliary content of a public report, such disclosure weakens the comprehensive measurement of enterprise value by carbon accounting. The role, while reducing the public's emphasis on carbon accounting information.

\section{Countermeasures and Suggestions for the Development of Carbon Accounting in Electric Power Enterprises}

\subsection{Establish a carbon accounting structure system for power companies and formulate carbon accounting information disclosure requirements}

As a representative of high-carbon enterprises, power companies' carbon accounting information will have a significant impact on company and investor decision-making. Therefore, China should build a carbon accounting structure system for power companies as soon as possible, and formulate carbon accounting information disclosure requirements, thereby standardizing the ways and 
contents of carbon accounting information disclosure for power companies, enhancing the comparability of carbon information among enterprises, and meeting the requirements of relevant information users.

\subsection{Integrating environmental externalities into the enterprise value measurement system}

The existing accounting system has the disadvantages of not considering the externalities of business operations. Carbon accounting information can more accurately measure the impact of enterprises on the environment, thus affecting the value of enterprises. In addition, the revised corporate value can also increase management's emphasis on carbon accounting information, thereby enhancing the initiative of enterprises to save energy and reduce emissions.

\subsection{Enhance the power enterprise information system}

The power industry is an information-intensive industry, and information including accounting information can be effectively collected, processed, and delivered as the key to improving management efficiency in power companies. To this end, major power companies should build a system-wide information system that not only ensures energy-saving emission reduction, but also controls carbon-related costs and maximizes the combination of economic and social benefits.

\subsection{Improve the internal governance system of power companies}

At this stage, carbon accounting behaviors including power information disclosure by power companies are mostly voluntary behaviors. A sound internal governance system and effective internal supervision are the basis for improving the quality of carbon accounting information. Therefore, improving the internal governance system of power companies is one of the important prerequisites for the effective implementation of carbon accounting. Power companies can enhance the independent director system, enhance the status of independent directors, and improve the supervisory role of independent directors in fulfilling corporate social responsibility.

\subsection{Deepen the knowledge structure of accounting practitioners in power companies}

Carbon accounting has a broad disciplinary base, and only proficient in financial accounting knowledge may not meet the needs of carbon accounting promotion. In order to enable carbon accounting to be implemented smoothly in power companies, it is necessary to deepen the implementation structure of accounting practitioners in power companies, transform traditional concepts and perspectives, and thus adapt to the needs of carbon accounting implementation of power companies.

\section{Summary}

The disclosure of carbon accounting information in the power industry will inevitably increase the cost of enterprises in the short term. However, in the long run, it is of far-reaching significance to disclose carbon accounting information in a timely and effective manner, which is beneficial to enterprises to actively undertake social responsibility and promote energy conservation and emission reduction in China. China's power industry carbon accounting information disclosure is still not perfect, but with the continuous efforts of the industry and the theoretical community, it will certainly be better developed.

\section{References}

[1] $\mathrm{Xu}$ Rong. Analysis on Several Issues of Environmental Protection Tax Law[J].Journal of Chongqing Vocational College of Electronic Engineering,2018(04):34-37.(In Chinese)

[2] Alfsen, K.H., Bye T. and Lorentsen L. Natural resource accounting and analysis: the Norwegian experience 1978-1986 [M].Central Bureau of Statistics,1987:79-83.

[3] Stewart Jones, Janek Ratnatunga. An inconvenient truth about accounting: The Paradigm Shift Required in Carbon Emissions Reporting and Assurance, American Accounting Association [J].Annum Meeting,Anaheim CA,2008(7):25-28. 
[4] Kolk,A.,D.Levy \& J. Pinkse. Corporate Response in an Emerging Climate Regime: The Institutionalization and Commensuration of Carbon Disclosure [J].European Accounting Review,2008(17):719--745.

[5] Francisco Ascui, Heather Lovell. As frames collide: making sense of carbon [J].Accounting, Auditing \& Accountability Journal,2011(8):978-993.

[6] Wang Aiguo. My carbon accounting concept[J].Accounting Research,2012(05):3-9+93.(In Chinese)

[7] Liang Liang. Discussion on the treatment method of carbon accounting[J].Business,2018,(6):9. DOI:10.3969/j.issn.1673-4041.2018.06.009.(In Chinese)

[8] Ge Jialu, Li Ruoshan. A New Trend of Thought in Western Accounting Theory in the 1990s---Green Accounting Theory[J].Accounting Research,1992(5):3-9.(In Chinese)

[9] Wang Yan, Li Yapei. Accounting Confirmation and Measurement of Carbon Emission Rights[J].Management Observation,2008(25):122- 123. (In Chinese)

[10]He Hongfeng, Liu Guichun. On the Accounting Confirmation and Measurement of Carbon Emission Rights[J].China Township Enterprise Accounting,2010(5):65- 66. (In Chinese)

[11]Zhang Peng. Research on the Confirmation and Measurement of Carbon Assets[J] .Financial Accounting Research,2011 (5):40- 42. (In Chinese) 